\title{
A Framework for Developing Competencies in Open and Distance Learning
}

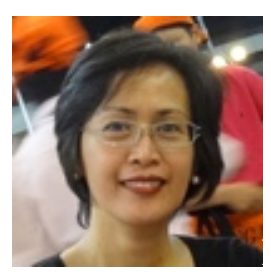

Patricia B. Arinto

University of the Philippines - Open University

\section{Abstract}

Many open universities and distance education institutions have shifted from a predominantly print-based mode of delivery to an online mode characterised by the use of virtual learning environments and various web technologies. This paper describes the impact of the shift to open and distance e-learning (ODeL), as this trend might be called, on the course design practices of faculty members at a small single-mode distance education university in the Philippines. Specifically, the paper presents and analyses the faculty's perspectives on how their course design practices have changed and issues and challenges arising from these changes. The findings suggest that faculty training programs in ODeL should aim to develop a comprehensive range of ODeL competencies in a systematic and coherent way. Based on the findings, as well as research on practitioner development in teaching effectively with technology, a framework for developing ODeL competencies among faculty is proposed. Aside from covering the four areas of change in course design practice identified in the study, the framework also specifies levels of expertise (basic, intermediate, and advanced), indicating degrees of complexity of the knowledge and skills required for each area at each level. All of the competencies listed for all four areas at the basic level comprise the minimum competencies for teaching an online distance education course.

Keywords: Open and distance e-learning 


\section{Introduction}

Since the mid-1990s significant changes have been taking place in the field of distance education (DE) as a result of rapid advances in information and communications technology (ICT). Many DE institutions have shifted from a print-based mode of delivery to online delivery characterised by the use of virtual learning environments (VLEs) and various web technologies (Haughey et al., 2008; Bates, 2008). Flexibility and adaptability of design distinguish 21st century DE from older forms of DE (Garrison, 2000; Haughey et al., 2008; Tait, 2010). Industrial era DE deployed "standardised, normalised and formalised procedures for design and delivery" (Peters, cited in Burge \& Polec, 2008, p. 238). In contrast, in online DE the boundary between course development and course delivery is increasingly blurred, and "former course development roles... are being deconstructed and reinvented" (Abrioux, 2001, p. 1) as the role of teachers in the design of pedagogically effective learning environments receives renewed emphasis (Anderson, 2008; Bennett et al., 2009). Moreover, DE course designs are increasingly resource-based (Calvert, 2005; Naidu, 2007), that is, featuring online learning activities organised around web-based resources (J ara \& Fitri, 2007) and, in some cases, integrated (Mason, 1998) or online discussion-based (J ara \& Fitri, 2007), where the course contents are "more fluid and dynamic" because they are created during synchronous and asynchronous online collaborative activities (Mason, 1998).

At the University of the Philippines - Open University (UPOU), resource-based course development has been encouraged since 2003 (Arinto, 2009), and it was bolstered with the university's adoption in 2007 of Moodle, an open source VLE that allows for the creation of courses featuring digital resources and online activities (Blin \& Munro, 2008). New courses are being developed under a resource-based course development contract, and faculty assigned to teach (called faculty-in-charge or FIC) already developed courses are encouraged to supplement the print modules (or replace them altogether, if warranted) with open educational resources (OER). FICs are also encouraged to integrate online discussion forums, and they are free to use open source web tools, such as blog sites, media sharing sites, and web-based conferencing applications, to enhance course delivery.

These changes in the design and delivery of courses have led some of UPOU's administrators, most notably the chancellor ${ }^{1}$, to coin the term open and distance e learning or ODeL to refer to UPOU's DE practice. ${ }^{2}$ ODeL highlights the convergence of

1 The chancellor is the equivalent of a rector or vice-chancellor in the UK system.

2 In February 2012, UPOU organised the 1st International Conference on Open and Distance e-Learning. More than 200 participants from 20 countries participated. The conference Web site is at http://icodel.upou.edu.ph/ 
the philosophy of open learning espoused by open universities and the DE and elearning pedagogies and technologies adopted by these institutions to enable flexible learning, independent learning, and the building of learning communities. ODeL may be considered to be an expansion of the term open and distance learning or ODL, which refers to "[a] learning system that combines open learning characteristics with distance delivery" (Abrioux, 2006, p, 10), to include the adoption of e-learning or online learning methodologies. In this paper, ODeL is used synonymously with online DE.

This paper reports part of the findings of a qualitative study of the ODeL course design practice of 10 UPOU academics. The study looked into the pedagogical rationales for the faculty's use of web technologies and their approaches to and perspectives on ODeL course design, their perspectives on how their course design practices have changed and issues and challenges arising from these changes, as well as the implications of these for faculty development in ODeL across the institution. Based on the study's findings as well as research on practitioner development in teaching effectively with technology, the paper proposes a framework for developing ODeL competencies among faculty of DE institutions that are in transition towards online modes of delivery.

\section{Methodology}

UPOU is a single-mode DE institution within the conventional or campus-based University of the Philippines (UP) system. ${ }^{3}$ It was established in 1995 "to democratise access to quality higher education" through the offering of DE programmes, especially in disciplines "that contribute to national development" (UPOU, no date). All of UPOU's programmes are designed for part-time students, and they are cohort- and term-based.

The research participants consist of eight regular or full-time faculty members ${ }^{4}$ and two affiliate faculty administrators who have been closely involved with the institution since its establishment. The eight regular faculty members comprise about a third of the total number of regular UPOU faculty. All 10 research participants were selected for this study because they are involved in course design and development aside from course delivery, unlike part-time lecturers who are contracted to serve only as course tutors during course delivery; and they have integrated or are integrating in their courses a range of web-based tools and resources, including rich media, blogs and wikis, web

\footnotetext{
3 Abrioux (2006) refers to this as the "university within a university" model, an institutional arrangement designed to "protect the ODL culture in a dual-mode institution" (p. 5).

$4 \quad$ UPOU's faculty complement consists of 27 full-time mostly middle-ranking faculty members (i.e., with the rank of assistant and associate professor [16]), and about 200 part-time faculty most of whom are faculty affiliates from the other UP units.
} 
conferencing, multimedia sharing, and social networking applications. Moreover, they have experienced different 'generations' of course design at UPOU: Three of them were course authors in the mid- to late-1990s, the heyday of the pre-packaged and tutorialin-print model; three joined UPOU during the transition period from face-to-face to online tutorials in 2001-2003, and they participated in the development of instructional materials for non-formal courses; three joined UPOU in 2004-2006 and have been involved in (online) course delivery (i.e., tutoring) more than in course development; and three joined UPOU in 2007 and they are implementing a web-based course development model.

Three of the participants are male and seven are female, reflecting the predominance of female faculty members in the university as a whole. In terms of rank, three participants are assistant professors, four are associate professors, and three are full professors. Four of the participants have at least 10 years experience in teaching at a distance, two have more than five years experience, and four have less than five years experience. They teach courses from different disciplines: biology, nursing, reading education, media studies, development communication, public management, R\&D management, and environment and natural resources management. All teach graduate-level courses, and four teach undergraduate-level courses as well.

Data collection was done through semi-structured interviews because course design is a purposeful activity that involves making deliberate choices of content and instructional strategies to achieve specific curricular outcomes based on the designer's understanding of the learning context, including the nature of the subject matter, the type of learner, and the resources and tools available (Goodyear, 2009); and especially in courses designed by faculty members working alone or independently (instead of in course teams), course design is influenced by the teacher-designer's personal constructs, which consist of personal experiences of learning, including those shaped by culture, gender, and ethnicity; personal views of what makes for 'good' teaching; and beliefs about the purposes of the subject (Leach \& Moon, 2000; Banks, Leach, \& Moon, 2005). The intentions and personal constructs that influence design are best accessed by asking the designer directly what he/she intended to do or achieve, and why. Thus, research participants were asked questions that were designed to explore their awareness of various elements of online course design, in particular strategies (what web tools and resources are used and how they are used); intentions (why the faculty use these technologies and what they intend to achieve); and perceptions particularly of the factors that shape/influence their actions and intentions, and how their teaching practice has evolved or is evolving.

The interviews were conducted over a one-week period. Each interview lasted between 45 and 90 minutes. They were conducted in UPOU offices that were convenient to the interviewees and which afforded privacy and quiet (e.g., a small conference room, the interviewee's office). All interviews were conducted in English, the official medium of instruction in higher education in the Philippines and one of the country's two official languages (the other is Filipino), and they were audio recorded and transcribed. 
During the first stage of data analysis, in addition to the analysis of individual participants' responses to the interview questions, responses to each question from all of the research participants were compared and contrasted in order to identify similarities and differences and formulate categories of responses to each question. This was in keeping with the 'collective case study' (Stake, 1995) methodology where individual case studies 5 are jointly analysed in order "to provide insight into an issue" (Stake, 2003, p. 137) or to formulate an analytic generalisation, defined as "the development of a theory which helps in understanding other cases or situations" (Robson, 2002, p. 177). In this study, the course design practices of 10 academics are examined in order to understand the phenomenon of online distance learning at UPOU. The focus is therefore not the course design practices of individual faculty members per se, but their collective practice of course design and the institutional ODeL 'profile' at a specific historical moment.

In the second stage of data analysis, the faculty's responses to the interview questions were analysed using a framework derived from the theoretical and empirical literature on how teaching with web technologies impacts on DE course design. This includes research on (1) the changing roles of teachers particularly in relation to course design, (2) variation in teachers' approaches to e-learning design, and (3) the development of teacher knowledge of and through e-learning design.

\section{Conceptual Framework}

Research on the changing role of teachers in online learning notes that some teaching roles are given greater emphasis or amplified while other roles are reduced as a result of the selectivity of technologies (Kanuka \& Rourke, 2008). That is, technologies are designed for particular purposes (referred to as their intentionality) and "[t]hey facilitate, emphasise, and enhance particular kinds of experience, while inhibiting, limiting, and sometimes even excluding others" (Swan, 2010, p. 110). The design role of teachers, for example, is amplified in online learning. According to Beetham and Sharpe (2007), while design is a key feature of teaching in general, in e-learning "the need for intentional design becomes more obvious and pressing" (p. 7). While in face-to-face teaching, approaches can be immediately adjusted to fit learners' needs which teachers can gauge directly from learner performance, in technology-supported learning seemingly ordinary pedagogical activities like grouping learners, posing questions, providing resources, and other ways of scaffolding learning in response to learner cues

5 These individual cases are referred to (by Stake, 1995; 2003) as instrumental case studies because unlike an intrinsic case study which is undertaken to understand the uniqueness of a specific phenomenon or case, they are conducted to help provide a general understanding of a phenomenon that extends beyond single unique cases (Harling, 2002). 
during the learning process "require forethought and an explicit representation of what learners and teachers will do" (Beetham \& Sharpe, p. 7). At the same time, new digital technologies are enabling design 'on the fly' (Oliver, 2004, p. 6). Mason (1995) includes in her typology online DE course models where "less of the course is pre-determined and more is created each time the course is delivered, through the discussions and activities" that take place on the VLE. The focus of design therefore shifts from "the design and delivery of instruction and instructional materials" to "the creation of environments that foster and support active learning in collaborative communities" (Swan, 2010, p. 114). In these "resource- and activity-based learning environments" (Naidu, 2008, p. 250), "university teachers have to think carefully about the design of good learning tasks... as well as about the resources that students will need if they are to stand a reasonable chance of succeeding in these activities" (Goodyear, 2010, p. 4). Thus, the mediating role of the teacher is expanded to include helping learners "to make sense of the wealth of resources which they can, with guidance, find themselves" (Tait, 2010, p. x).

This type of scaffolding of learning that online teachers are called upon to provide is evident in what Siemens (2007) refers to as the curatorial role of teachers in networked learning environments. Siemens proposed the idea of teachers as curators as an alternative to the simplistic dichotomy of sage on the stage versus guide on the side. According to Siemens (2007), the term curating underscores the complexity of selecting resources for learning: It is work that involves being a subject specialist with the ability to make decisions about what resources to select, provide expert commentary about each resource or the resources as a group, and showcase resources in ways that highlight each resource as well as the relationships among them. This work has the important effect of facilitating or scaffolding learning particularly of disciplinary canons:

A curator balances the freedom of individual learners with the thoughtful interpretation of the subject being explored. While learners are free to explore, they encounter displays, concepts, and artefacts representative of the discipline. Their freedom to explore is unbounded. But when they engage with subject matter, the key concepts of a discipline are transparently reflected through the curatorial actions of the teacher. (Siemens, n.p.)

While the design role of teachers might be amplified in online learning environments, a qualitative change in design practice, for example shifting from designing content to designing learning activities, does not necessarily happen unless teachers recognise the need for such changes. This recognition in turn comes from a broadening of the teachers' awareness of the pedagogic opportunities afforded by learning technologies and the development of their knowledge and skills in online learning design. This was found to be the case by Armellini and Jones (2008) in a study on the impact on elearning design practice of a two-day design workshop involving 93 faculty members of 
the University of Leicester. Specifically, they found that faculty move through three stages of e-learning design: 1) transmissive design, 2) interactive design, and 3) design for knowledge construction. Transmissive design is characterised by a focus on providing resources for students, using the learning platform as a repository of materials, and student interaction with tutors being limited to submitting assignments for marking. Interactive design, also referred to as interactive, single loop design, fosters limited participation typically by asking participants to post in discussion forums their experiences with the course material. Because the discussion tends to be limited to one response to the task posed by the teacher, with little or no further exchanges among students, interactive design is characterised as being closer to teacher-centred rather than learner-centred approaches and as having a strong focus on content. In collaborative designs, which is considered to be learner-centred, multiple-loop interaction and collaboration among learners and tutors is central to learning and the teacher's role is to design 'e-tivities', encourage collaboration, and ensure meaningful student engagement through 'e-moderation'. According to Armellini and Jones, although course teams did not all change "in the same way or at the same speed,... all showed signs of change towards the collaborative category" (p. 25) after going through the design workshop, and course teams that opted to maintain a transmissive approach to e-learning developed an awareness of alternative approaches as well as key pedagogical issues in technology-supported learning.

Pedagogic change in online learning might also be understood in terms of the development of the teacher's knowledge of how to teach effectively with technology. Mishra and Koehler (2006) have proposed the technological pedagogical content knowledge framework (TPCK or, more recently, TPACK; see Figure 1) for understanding the nature of this knowledge as one that goes beyond technology-related competencies to include knowledge of subject matter or content and pedagogical knowledge as well as the integrated forms of knowledge that develop in the interplay among these three main forms, namely, technological pedagogical knowledge (TPK), technological content knowledge (TCK), and pedagogical content knowledge (PCK, first proposed by Shulman in 1986). Mishra and Koehler (2006) have noted that TPACK is developed by engaging continuously in the design of technology-supported learning. According to Angeli and Valanides (2009), this continuous practice should lead to the transformation of the forms of knowledge that comprise TPACK and not just the increase or accumulation of each component. Moreover, "teachers need to be explicitly taught about the interactions among technology, content, pedagogy, and learners" in order to effectively use technology to improve learning (Angeli \&Valanides, p. 158). 


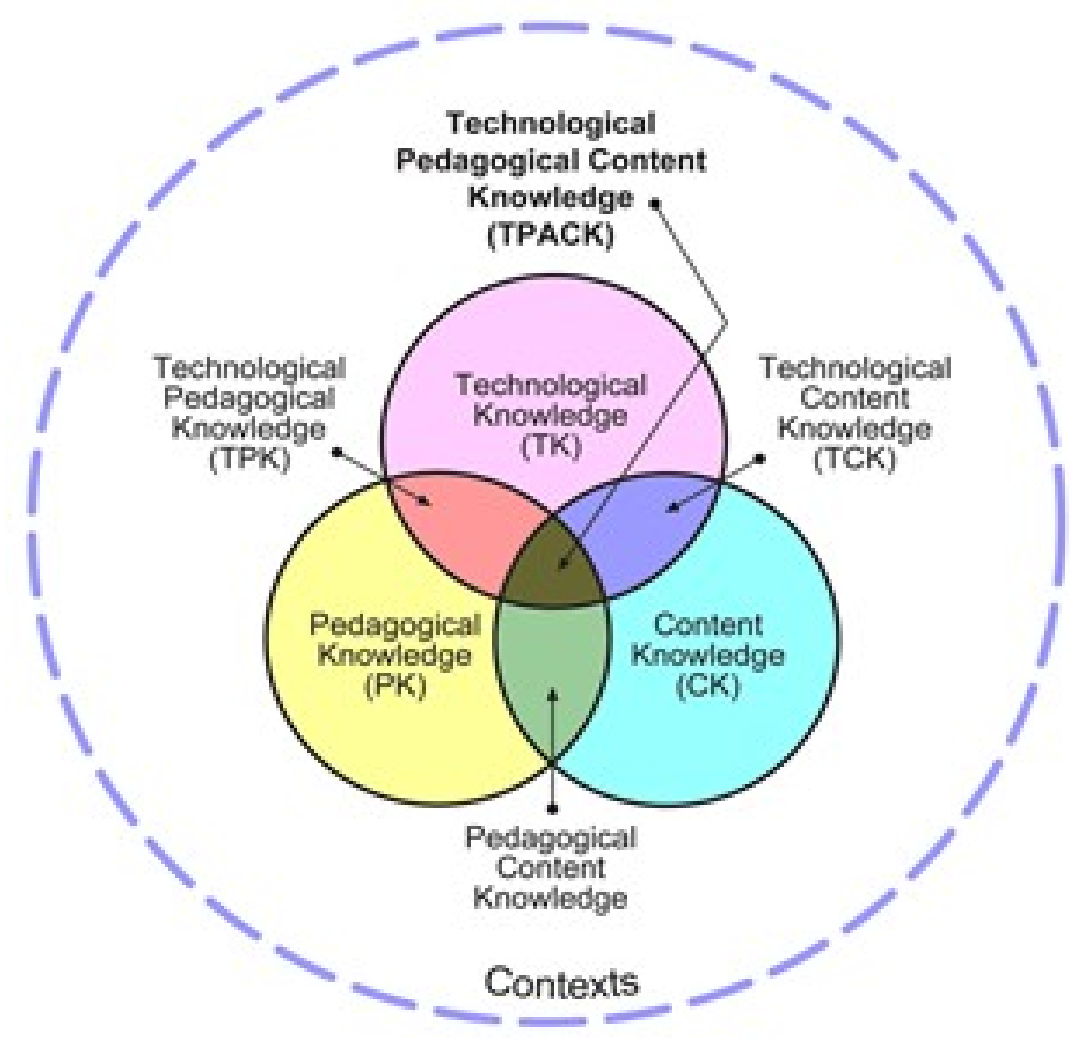

Figure 1. The TPACK framework (http:// tpack.org).

\section{Fndings and Discussion: Changes in Course Design Practice at UPOU}

In the current study, the faculty described changes in four aspects of course design: content development, teaching strategies, learning activities, and assessment of learning (Table 1). 
Table 1

Summary of Changes in Participants' Course Design Practice

\begin{tabular}{|c|c|c|c|}
\hline $\begin{array}{l}\text { Changes in content } \\
\text { development }\end{array}$ & $\begin{array}{l}\text { Changes in teaching } \\
\text { strategies }\end{array}$ & $\begin{array}{l}\text { Changes in learning } \\
\text { activities }\end{array}$ & Changes in assessment \\
\hline $\begin{array}{l}\text { including learning } \\
\text { resources in various } \\
\text { formats (P1, P2, P9) } \\
\text { frequent updating of } \\
\text { the course package (P2, } \\
\text { P6) } \\
\text { inclusion of learning } \\
\text { resources that learners } \\
\text { can also use in their } \\
\text { own professional } \\
\text { context (P2) } \\
\text { being able to customise } \\
\text { a course through the } \\
\text { inclusion of sample } \\
\text { texts from the students' } \\
\text { field of study (P5) }\end{array}$ & $\begin{array}{l}\text { using web tools to } \\
\text { implement a process- } \\
\text { oriented, synchronous } \\
\text { discussion-based course } \\
\text { model (P5) } \\
\text { exploiting LMS } \\
\text { functionalities to } \\
\text { structure/ organise the } \\
\text { course better (P5) } \\
\text { use of web tools in a "lab” } \\
\text { course requiring } \\
\text { demonstrations and } \\
\text { hands-on exercises (P8) } \\
\text { being able to include } \\
\text { synchronous discussion } \\
\text { (P9) }\end{array}$ & $\begin{array}{l}\text { using a variety of } \\
\text { learning activities to } \\
\text { motivate students (P3) } \\
\text { scaffolding learning } \\
\text { (P3) } \\
\text { involving students } \\
\text { more in the teaching } \\
\text { and learning process; } \\
\text { enabling greater } \\
\text { student participation } \\
\text { (P2, P9) } \\
\text { enabling collaborative } \\
\text { learning (P4, P8, P9) } \\
\text { fostering dialogue and } \\
\text { community-building } \\
\text { (P5, P7) }\end{array}$ & $\begin{array}{l}\text { more holistic } \\
\text { assessment through } \\
\text { use of formative and } \\
\text { summative } \\
\text { assessment, and } \\
\text { different types of } \\
\text { assessment (not just } \\
\text { tests) (P1) } \\
\text { adoption of different } \\
\text { formats for student } \\
\text { work (i.e. aside from } \\
\text { print or text) (P1, P3, } \\
\text { P7) } \\
\text { specification of } \\
\text { assessment criteria to } \\
\text { guide students better } \\
\text { (P4) }\end{array}$ \\
\hline
\end{tabular}

(Note: The participant/s who mentioned a particular change is/are identified in parentheses after each item. The participant reference is $P$ plus a number from 1 to 10.)

The changes mentioned under content development and learning activities are consistent with those noted in DE research (for example by Haughey et al., 2008; Mason, 1998; Naidu, 2007; Tait, 2010), in particular the shift from pre-packaged to resource-based content development and from materials development to the design of learning environments and activities. These are said to be evidence of a shift from teacher-focused knowledge transmission pedagogies to learner-focused social constructivist knowledge generation pedagogies (Goodyear, 2009; Swan, 2010). In contrast, changes in teaching strategies and assessment were described in more teacherfocused terms. More specifically, the increasing use of web technologies for synchronous communication appears to be enabling teaching strategies which might foster greater teacher-learner interaction but which might also constrain learner access and participation (Murphy et al., 2011). Assessment practice also appears to still be teacherdirected, with little use of student self- and peer-assessment, which confirms Mason's 
(2008) comment regarding the paucity of innovative assessment design in online courses.

This analysis finds further support in the faculty's description of aspects of their course design practice that have been weakened or reduced by using web technologies and their perception of gaps between what they design for and what takes place in practice. Paradoxically, these gaps and weaknesses were in the same areas of course design that they referred to as having been strengthened (Table 2).

Table 2

Issues and Challenges in Personal ODeL Course Design Practice

\begin{tabular}{ll} 
Aspect & Weakness/ issue/ challenge \\
\hline $\begin{array}{l}\text { Content } \\
\text { development }\end{array}$ & Time needed for selecting resources (P1, P2, P8)
\end{tabular}

Development of study guides (P2, P4, P6)

Teaching strategies Reduction of opportunities to lecture (P6, P10)

Learning activities Over-reliance on tool and failure to consider effects on learners/ learning (P3, P4)

Fostering learner engagement and participation (P1, P3, P6, P8, P9)

Spontaneity and immediacy (P2, P7)

Control of learner behaviour (P5)

Assessment

Fairness in assessment of learning (P7)

Providing learner support (P7)

Giving timely feedback (P4)

While many of the faculty mentioned access to numerous learning resources as one of the benefits of teaching with the Web, they also noted that this has made the resource 
selection task of teachers more complicated. Aside from more time being spent on evaluating materials, the sheer volume of resources to choose from can prove confusing and overwhelming, resulting in poor choices of resources to recommend to learners (a problem noted by P8). P2 referred to this as the challenge of curatorship: "Actually, the problem is how to choose, the time that you have to spend for curating." In addition, since web resources have been created for other contexts, teachers need to spend time on developing study guides to help learners make productive use of these resources (as P4 pointed out). However, faculty members (like P6 in this study) tend to neglect the development of study guides. This might be because in face-to-face teaching, texts are usually discussed in class, which reduces the need for a written study guide. Another reason is that writing study guides is associated with the older DE course development model of writing stand-alone or self-contained course materials, and this model is being supplanted by the newer resource-based approach to course development. As P4's comments on this point suggest, in the resource-based model how much guidance to give to students in the form of written materials can pose a dilemma for faculty. There can be too little guidance or too much, both of which would be detrimental to learning.

Providing relevant guidance in a timely manner is also an issue. Being able to provide just-in-time instruction is one of the affordances of web technologies for distance teaching. Access to web-based resources that can be easily re-purposed for instruction and the availability of tools for faculty to assemble course packages on their own (Muirhead, 2005) mean that course development is now more open-ended and flexible (Mason, 1999). Faculty members (like P7 in this study) generally consider this to be an advantage. However, the increased flexibility for teachers, for example with regard to when to post course materials, does not necessarily mean greater flexibility for all learners (cf. Thorpe \& Godwin, 2007), as suggested by the student comments reported by $\mathrm{P} 4$ about how the unavailability of all course materials at the beginning of the term limits their ability to pace their own learning.

In the area of teaching strategies, some of the faculty expressed concern over the reduced opportunity in online teaching contexts for providing direct instruction via lectures. It appears that lecturing is still considered by some DE faculty to be synonymous with teaching. In some cases there seems to be the assumption that classroom-based face-to-face teaching is the standard practice not only in the sense of being the benchmark against which all modes of teaching are measured, but also in the sense of being the best practice that should be emulated. In this study, this is evident in some of the faculty's statements about being able to do online what is done face-to-face. The problem with this is that it can lead to failure to recognise the opportunities for innovation that online teaching opens up (Haythornthwaite \&Andrews, 2011).

Fostering learner participation through diverse learning activities is cited (by P3, P5, and P9) as one of the areas of teaching that is strengthened by web technologies. However, there is also the possibility of teachers becoming technology-centric in their design of online learning activities, such that "you don't foresee... the effect on the learning itself and how the students are using [the technology]" (P3). Online learning 
activities can be challenging even for students who are competent distance learners. P4 and P8 have noted that collaborative activities in particular can alienate (P8) some learners as they are constrained to follow group schedules instead of their own pace (Garrison, 2009).

For those like P7 who consider dialogue to be central to learning, there is dissatisfaction with the lack of spontaneity and immediacy in asynchronous computer-mediated interaction. Immediacy refers to the sense of physical or psychological closeness arising from particular communication behaviours (Woods \& Baker, 2004). In online courses, instructors can achieve immediacy by "ensuring a high degree of interactivity and participation" (Kearsley, cited in Woods \& Baker, 2004, p. 5) through class discussion, dialogue about complex issues, group projects, and authentic learning activities. However, although teachers can build in these types of activities (as P7 and others do), how the design will unfold is unpredictable. P5 cited the example of students engaging in heated argument in discussion forums as an example of this gap between the design for interaction and how interaction might take place. P5's example suggests the need to orient faculty not only to the technology-related and pedagogical aspects of online teaching but also the social and managerial aspects, including "how to prevent and/ or deal with inappropriate student behaviours when using the Internet and/or Web communication tools" (Kanuka, Heller, \&J ugdev, 2008, p. 137).

The assessment-related challenges mentioned by the faculty were difficulty in giving individualised feedback in a timely manner (P4) and difficulty in ensuring equity and fairness in assessment (P7). The need to provide individualised feedback to students is felt more in online learning where each student makes a written contribution. However, keeping track of student contributions and providing individualised feedback requires a lot of time (Coppola, Hiltz, \& Rotter, 2001). With regard to fairness and equity in assessment, P7 expressed concern about how to ensure that the different assessment options that she gives to her students meet the same standards of quality and enable learning to the same degree. According to Beetham (2007), flexible learning, where learners have a choice of what learning tasks to undertake, what technologies to use, and what evidence of learning to present for assessment, requires that "learners be supported in all the different choices they make". This is challenging "despite the capacity of technology to present a wider range of options" because "the limiting factor is the availability of skilled practitioners to provide relevant feedback and support" ( $p$. 33). 


\section{A Proposed Framework for Faculty Development in ODeL}

The findings presented in the preceding section suggest that faculty training programmes in ODeL should aim to develop a comprehensive range of ODeL competencies in a systematic and coherent way. It is not just technology-related skills (e.g., how to use a VLE) that faculty members need to develop in order to be able to teach effectively online. Based on the four areas of change in course design practice identified in the study (i.e., content development, learning activities, teaching strategies, and assessment) and related research, the following framework of ODeL skills is proposed (see Table 3).

Table 3

Proposed Framework of Developing ODeL Skills

Areas Basic Intermediate Advanced

Content updating course content using development web resources

selecting web resources with learning outcomes in mind

writing study guides

complying with copyright and exemptions from copyright selecting web resources in selecting web all media types

including resources for supplementary study (aside from core resources) producing OER using OER repositories resources to cater to different sets of learners
Design of learning activities designing online learning activities to engage learners and facilitate understanding of content

writing activity guides

providing resources and tools designing online learning designing online activities to foster dialogue collaborative and a community of inquiry knowledge generation learning activities
Teaching strategies differentiating the roles of the

online teacher from those of the f2f teacher

providing direct instruction online
establishing teaching
adopting
presence
participatory
performing "new" teaching roles online
pedagogies (students
as co-creators)
organising and conducting
teaching with others
("teaching with 
organising the course site

managing workload

Assessment designing summative assessment

writing assignment guides (including criteria for marking)

providing timely and

constructive feedback online discussions

networks")

designing formative

assessment

ensuring a balance and

coherence between

summative and formative

assessment

using alternative

assessment, including

student self- and peer-

assessment designing flexible

assessment

Following the principle that effective teaching with technology requires the integration of knowledge of content, pedagogy, and technologies for learning, or TPACK (Koehler \& Mishra, 2006; Angeli \& Valanides, 2010), the framework does not list technology skills separately from pedagogical skills and content-related skills. Instead, the competencies indicated for each of the four areas at a particular level of expertise are TPACK competencies. For example, selecting web resources with learning outcomes in mind (under basic level content development) requires a course designer to integrate knowledge of a particular course and its target learning outcomes in a programme of study (i.e., subject matter knowledge, curricular knowledge), knowledge of how the course is best taught and/or how particular learning outcomes are best achieved (pedagogical knowledge), and knowledge of how to locate web resources (technological knowledge, in particular internet skills) and evaluate their relevance to the subject matter and their usefulness for helping learners achieve the target learning outcomes (subject and pedagogical knowledge as well as media literacy).

The proposed framework also specifies levels of expertise (basic, intermediate, and advanced), indicating degrees of complexity of the knowledge and skills required for each area at each level. All of the competencies listed for all four areas at the basic level comprise the minimum competencies for teaching an online distance education course. Anyone who is assigned to teach an online course at UPOU should have, or should be helped to develop, these minimum competencies. It should be noted that the framework as presented lists only the key skills derived from the findings of the current study. The list of key skills may be expanded as needed.

In conclusion, it is important to note that training programmes by themselves are not sufficient for the professional development of ODeL practitioners. Based on the research 
participants' descriptions of the evolution of their course design practice, it is clear that professional development in ODeL is a complex process that requires continuous engagement in design work, critical reflection, and membership in a community of practice. Thus, training in course design should be part of a holistic and integrated faculty development programme in ODeL which would include not only workshops but also opportunities to undertake experiments, to learn alone or with a partner or with a small group, and to share experiences and critical reflections as well as 'products' of innovation, using a whole range of tools and resources (toolkits) and with appropriate and effective administrative and research support. The research participants' perspectives on the issues and challenges in ODeL course design at the personal and institutional levels underscore the value of these "mechanisms for innovation in teaching and learning" (Laurillard, 2008, p. 529). 


\section{References}

Abrioux, D. (2001). Guest editorial. International Review of Research in Open and Distance Learning, 1(2). Retrieved from http:// www.irrodl.org/ index.php/irrodl/issue/ view/ 10

Abrioux, D. (2006). Athabasca University, Canada: An evolution of an existing institution. In S. D'Antoni (Ed.), The virtual university: Models and messages; lessons from case studies. UNESCO International Institute for Educational Planning. Retrieved from http:// www.unesco.org/iiep/ virtualuniversity/media/document/Ch9_Athabasc a Abrioux.pdf.

Anderson, T. (2008). Teaching in an online learning context. In T. Anderson (Ed.), The theory and practice of online learning (pp. 343-365). Edmonton, AB: Athabasca University Press.

Angeli, C., \& Valanides, N. (2009). Epistemological and methodological issues for the conceptualization, development, and assessment of ICT-TPCK: Advances in technological pedagogical content knowledge (TPCK). Computers \& Education, 52, 154- 168.

Arinto, P. B. (2009). Untitled personal narrative. 100 Narratives. Los Banos, Laguna: University of the Philippines Open University.

Armellini, A., \& J ones, S. (2008). Carpe diem: Seizing each day to foster change in elearning design. Reflecting Education, 4(1), 17-29.

Banks, F., Leach, J., \& Moon, B. (2005). Extract from new understandings of teachers' pedagogic knowledge. Curriculum J ournal, 16(3), 331-340.

Bates, T. (2008). Transforming distance education through new technologies. In T. Evans, M. Haughey \& D. Murphy (Eds.), International handbook of distance education. Emerald Group Publishing Ltd.

Beetham, H. (2007). An approach to learning activity design. In H. Beetham \& R. Sharpe (Eds.), Rethinking pedagogy for a digital age. London and New York: Routledge.

Beetham, H., \& Sharpe, R. (Eds.) (2007). Rethinking pedagogy for a digital age. London and New York: Routledge.

Bennett, S., Agostinho, S., Lockyer, L., \& Harper, B. (2009) Researching learning design in open, distance, and flexible learning: Investigating approaches to supporting design processes and practices. Distance Education, 30(2), 175-177. 
Benson, R., \& Samarawickrema, G. (2009). Addressing the context of e-learning: using transactional distance theory to inform design. Distance Education, 30(1), 5-21.

Blin, F., \& Munro, M. (2008). Why hasn't technology disrupted academics' teaching practices? Understanding resistance to change through the lens of activity theory. Computers \& Education, 50, 475-490.

Burge, E. J . \& Polec, J . (2008). Transforming learning and teaching in practice: Where change and consistency interact. In T. Evans, M. Haughey \& D. Murphy (Eds.)., International handbook of distance education. Emerald Group Publishing Ltd.

Calvert, J . (2005). Distance education at the crossroads. Distance Education, 26(2), 227-238.

Cleveland-Innes, M. (2010). Teaching and learning in distance education: Enter a new era. In M. Cleveland-Innes \& D.R. Garrison (Eds.), An introduction to distance education. Understanding teaching and learning in a new era. New York and London: Routledge.

Coppola, N. W., Hiltz, S. R., \& Rotter, N. (2001). Becoming a virtual professor: Pedagogical roles and ALN. Proceedings of the 34th Hawaii International Conference on System Sciences. Retrieved from http:// csdl2.computer.org/ comp/ proceedings/hicss/2001/ 0981/01/09811003. pdf

Garrison, R. (2000). Theoretical challenges for distance education in the $21^{\text {st }}$ century: A shift from structural to transactional issues. International Review of Research in Open and Distance Learning, 4(2). Retrieved from http://www.irrodl.org/index.php/irrodl/article/view/2/22.

Garrison, R. (2009). Implications of online learning for the conceptual development and practice of distance education. J ournal of Distance Education, 23(2), 93104.

Goodyear, P. (2010). Teaching, technology and educational design: The architecture of productive learning environments. Senior Fellowship Final Report for the Australian Learning and Teaching Council.

Harling, K. (2002). An overview of case study. Retrieved from http:// www.farmfoundation.org/news/articlefiles/1028-1 harling.pdf

Haughey, M. (2010). Teaching and learning in distance education before the digital age. In M. Cleveland-Innes \& D.R. Garrison (Eds.), An introduction to distance education. Understanding teaching and learning in a new era. New York and London: Routledge. 
Haythornthwaite, C., \&Andrews, R. (2011). E-learning theory \& practice. London: Sage Publications Ltd.

J ara, M., \& Fitri, M. (2007). Pedagogical templates for e-learning. London: Institute of Education.

Retrieved

from http:// www.wlecentre.ac.uk/cms/files/occasionalpapers/wle_op2.pdf

Kanuka, H., Heller, B., \& Jugdev, K. (2008). The factor structure of teaching development needs for distance-delivered e-learning. International J ournal for Academic Development, 13(2), 129- 139.

Kanuka, H., \& Rourke, L. (2008). Exploring amplifications and reductions associated with e-learning: conversations with leaders of e-learning programs. Technology, Pedagogy and Education, 17(1), 5-15.

Laurillard, D. (2010). Supporting teacher development of competencies in the use of learning technologies. In ICT in Teacher Education: Policy, Open Educational Resources and Partnership. Proceedings of International Conference IITE2010 (pp. 63-74). Moscow: UNESCO Institute for Information Technologies in Education.

Laurillard, D. (2008). Technology enhanced learning as a tool for pedagogical innovation. J ournal of Philosophy of Education, 42(3-4), 52-533.

Leach, J., \& Moon, B. (2000). Pedagogy, information and communications technology and teachers' professional knowledge. Curriculum J ournal, 11(3), 385-404.

Mason, R. (1998). Models of online courses. ALN Magazine, 2(2). Retrieved from http:// www.old.sloanconsortium.org/publications/magazine/v2n2/ mason.asp

Mason, R. (2008). Preparing teachers and learners for new forms of assessment. In T. Evans, M. Haughey \& D. Murphy (Eds.), International handbook of distance education (pp. 513-528). Emerald Group Publishing Ltd.

Mishra, P., \& Koehler, M. (2006). Technological pedagogical content knowledge: A new framework for teacher knowledge. Teachers College Record, 108(6), 1017-1054.

Muirhead, B. (2005). A Canadian perspective on the uncertain future of distance education. Distance Education, 26(2), 239-254.

Murphy, E., Rodríguez-Manzanares, M. A., \& Barbour, M. (2011). Asynchronous and synchronous online teaching: Perspectives of Canadian high school distance education teachers. British J ournal of Educational Technology, 42(4), 583591.

Naidu, S. (2007). Instructional designs for optimal learning. In M. G. Moore (Ed.), Handbook of distance education. New York and London: Routledge. 
Oliver, M. (2004). Effective support for e-learning within institutions. Unpublished project report, JISC practitioners research study project. Retrieved from www.jisc.ac.uk/ uploaded_documents/Effective\%20support\%20instit\%20v2_M artin_Oliver.doc.

Robson, C. (2002). Real world research ( $2^{\text {nd }}$ ed). Oxford: Blackwell Publishing.

Sharpe, R., \& Oliver, M. (2007). Designing courses for e-learning. In H. Beetham \& R. Sharpe (Eds.), Rethinking pedagogy for a digital age (pp. 41-51). London and New York: Routledge.

Siemens, G. (2007). Networks, ecologies, and curatorial teaching. In Connectivism. Available online at http:// www.connectivism.ca/ ?p=93.1413

Stake, R. E. (1995). The art of case study research. Thousand Oaks, CA: Sage.

Stake, R. E. (2003). Case studies. In N.K. Denzin \& Y.S. Lincoln (Eds.), Strategies of qualitative inquiry (pp. 134-164). Thousand Oaks, CA: Sage.

Swan, K. (2010). Teaching and learning in post-industrial distance education. In M. Cleveland-Innes \& D.R. Garrison (Eds.), An introduction to distance education. Understanding teaching and learning in a new era (pp. 108-134). New York and London: Routledge.

Tait, A. (2010). Foreword. In M. Cleveland-Innes \& D.R. Garrison (Eds.), An introduction to distance education. Understanding teaching and learning in a new era (pp. ix-xi). New York and London: Routledge.

Thompson, M. M. (2007). From distance education to e-learning. In R. Andrews \& C. Haythornthwaite (Eds.). SAGE handbook of e-learning research (pp. 159-178). London: Sage Publications Ltd.

Thorpe, M., \& Godwin, S. (2006). Interaction and e-learning: The student experience. Studies in Continuing Education, 28(3), 203-221.

Woods, R. H., \& Baker, J.D. (2004). Interaction and immediacy in online learning. International Review of Research in Open and Distance Learning, 5(2).

\section{Athabasca University $\mathbf{7}$}

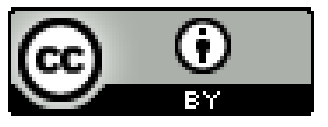

